\title{
Mercury reallocation in thawing subarctic peatlands
}

\section{M.F. Fahnestock ${ }^{1 *}$, J.G. Bryce ${ }^{1}$, C.K. McCalley ${ }^{2}$, M. Montesdeoca ${ }^{3}$, S. Bai ${ }^{4}$, Y. $\mathrm{Li}^{4}$, C.T. Driscoll ${ }^{3}$, P.M. Crill ${ }^{5}$, V.I. Rich ${ }^{4}$, R.K. Varner ${ }^{1,6}$}

Abstract

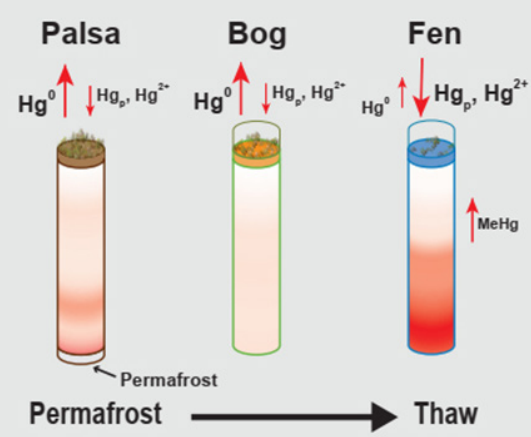

Warming Arctic temperatures have led to permafrost thaw that threatens to release previously sequestered mercury $(\mathrm{Hg})$ back into the environment. Mobilisation of $\mathrm{Hg}$ in permafrost waters is of concern, as $\mathrm{Hg}$ methylation produced under water-saturated conditions results in the neurotoxin, methyl $\mathrm{Hg}(\mathrm{MeHg})$. Thawing permafrost may enhance $\mathrm{Hg}$ export, but the magnitude and mechanisms of this mobilisation within Arctic ecosystems remain poorly understood. Such uncertainty limits prognostic modelling of $\mathrm{Hg}$ mobilisation and impedes a comprehensive assessment of its threat to Arctic ecosystems and peoples. Here, we address this knowledge gap through an assessment of $\mathrm{Hg}$ dynamics across a well-studied permafrost thaw sequence at the peak of the growing season in biologically active peat overlying permafrost, quantifying total gaseous mercury (TGM) fluxes, total mercury $\left(\mathrm{Hg}_{\mathrm{Tot}}\right)$ in the active layer peat, porewater $\mathrm{MeHg}$ concentrations, and identifying microbes with the potential to methylate Hg. During the initial thaw, TGM is liberated, likely by photoreduction from permafrost where it was previously stored for decades to centuries. As thawing proceeds, TGM is largely driven by hydrologic changes as evidenced by $\mathrm{Hg}$ accumulation in water-logged, organic-rich peat sediments in fen sites. $\mathrm{MeHg}$ in porewaters increase across the thaw gradient, a pattern coincident with increases in the relative abundance of microbes possibly containing genes allowing for methylation of ionic $\mathrm{Hg}$. Findings suggest that under changing climate, frozen, well-drained habitats will thaw and collapse into saturated landscapes, increasing the production of $\mathrm{MeHg}$ and providing a significant source of the toxic, bioaccumulative contaminant.

Received 27 April 2019 | Accepted 15 August 2019 | Published 14 October 2019

\section{Introduction}

Anthropogenic $\mathrm{Hg}$ emissions have increased $\mathrm{Hg}$ deposition to the Arctic three-fold since the Industrial Revolution (Fitzgerald et al., 2005). Terrestrial ecosystems are generally net sinks for atmospheric Hg deposition (Selin, 2009), and Hg sequestration in soil is positively correlated with organic matter content (Grigal, 2003; Smith-Downey et al., 2010). Permafrost constitutes the largest long term reservoir of $\mathrm{Hg}$, containing twice that of all other reservoirs combined (Schuster et al., 2018 and references therein). Changes in the organic carbon (OC) balance from thawing permafrost, coupled with changing redox conditions associated with increases in soil moisture result in the release of labile OC (Hodgkins et al., 2014) that likely drives $\mathrm{Hg}$ export (Mu et al., 2019). Reducing conditions favoured in fen environments also influence the bioavailability of $\mathrm{Hg}$ via binding to thiol functional groups (Skyllberg et al., 2003). Studies of northern peatlands find that $\mathrm{Hg}$ export accompanies permafrost thaw associated with climate change (e.g., Rydberg et al., 2010; St. Pierre et al. 2018; Mu et al., 2019). Increasing Arctic temperatures also contribute to significant changes in microbial communities and activity which can influence the production of methyl $\mathrm{Hg}(\mathrm{MeHg})$, a powerful neurotoxin (Barkay et al., 2011 and references therein; Yang et al., 2016). In this study we present a holistic view of $\mathrm{Hg}$ cycling across a permafrost thaw gradient that addresses the interactions of atmospheric, hydrologic and geochemical processes with ecosystem response to changing the distribution and methylating potential of $\mathrm{Hg}$ under permafrost thaw (detailed methods descriptions can be found in Supplementary Information).

Stordalen Mire in Abisko, Sweden ( $\left.68^{\circ} 22^{\prime} \mathrm{N}, 19^{\circ} 03^{\prime} \mathrm{E}\right)$ contains distinct sub-habitats sampled for this study. These representative sub-habitats along a permafrost thaw gradient common to northern peatlands include: i) permafrost-dominated, well-drained palsas occupied by feather mosses and ericaceous and woody plants (ii) intermediate permafrost sites with variable water table depth, dominated by Sphagnum spp.

\footnotetext{
1. Department of Earth Sciences, University of New Hampshire, Durham, NH, USA

2. Thomas H. Gosnell School of Life Sciences, Rochester Institute of Technology, Rochester, NY, USA

3. Department of Civil and Environmental Engineering, Syracuse University, Syracuse, NY, USA

4. Department of Microbiology, The Ohio State University, Columbus, OH, USA

5. Department of Geological Sciences, Stockholm University, Sweden

6. Institute for the Study of Earth, Oceans, and Space, University of New Hampshire, Durham, NH, USA

Corresponding author (email: florencia.fahnestock@unh.edu)
} 
a.

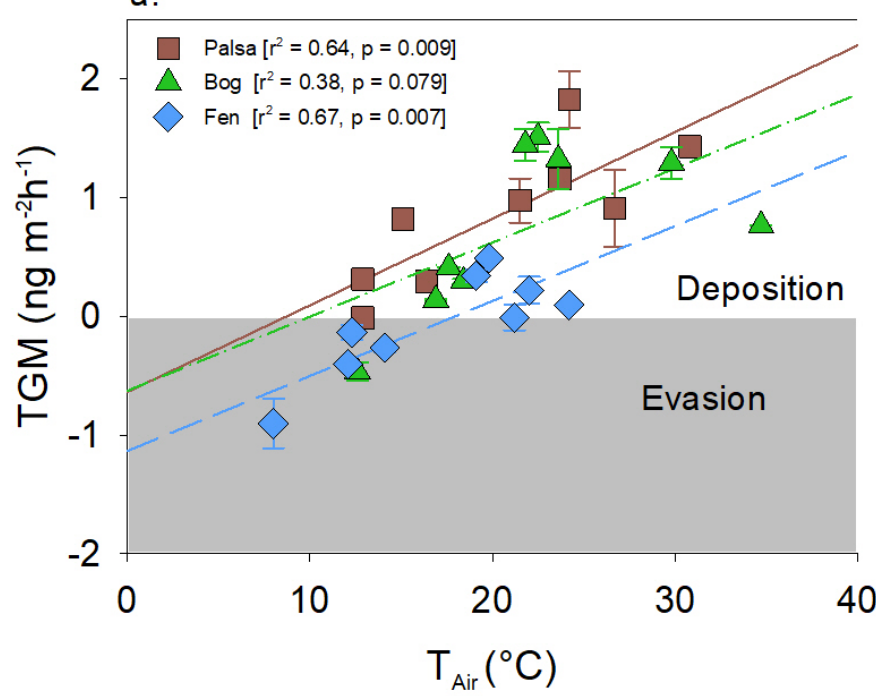

b.

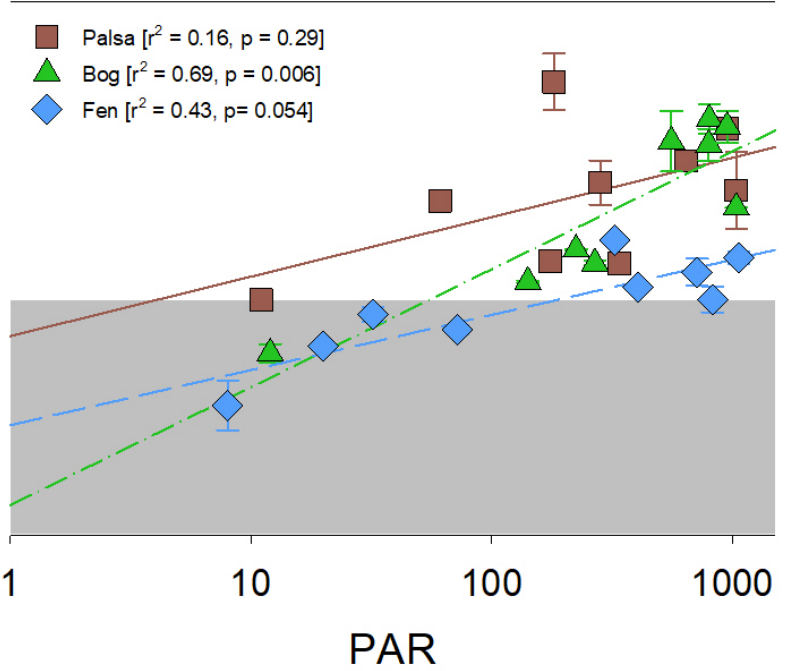

Figure 1 (a) Relationships between TGM flux and ambient air temperature $\left({ }^{\circ} \mathrm{C}\right)$ and $($ b) photosynthetically active radiation (PAR). Symbols denote palsa (brown squares), bog (green triangles) and fen (blue diamonds) and include least squares linear regressions and associated $r^{2}$ and $p$ values. Evasion of TGM interpreted for values greater than zero and deposition for values less than zero.

(iii) full summer-thaw, fully submerged sites with Eriophorum angustifolium (Fig. S-1). Between 1970 and 2000, permafrost thaw and palsa collapse led to the expansion of Sphagnum (bog) and Eriophorum (fen) by $3 \%$ and $54 \%$, respectively (Johansson et al., 2006a). Linking thawing permafrost with hydrologic change (Johansson et al., 2006b), vegetation shifts over a 30 year period (Malmer et al., 2005; Johansson et al., 2006a) and carbon dynamics in a mire (e.g., Öquist and Svensson, 2002; Bäckstrand et al., 2010) provide essential context to develop a predictive framework for $\mathrm{Hg}$ cycling in the future thawed permafrost.

\section{Results and Discussion}

\section{Mechanisms driving $\mathrm{Hg}$ cycling in Arctic ecosystems}

1. Evasion. Full quantification of $\mathrm{Hg}$ mobilisation requires an assessment of the dynamics of $\mathrm{Hg}$ exchange at the atmosphere-land interface. During three days of dynamic chamber flux measurements (in the peak of the growing season) all three sites exhibited a diel pattern in TGM fluxes, as shown in previous studies (Carpi and Lindberg, 1997; Poissant et al., 2004; chamber flux measurement approach described in Supplementary Information). Evasion of TGM occurred during warmer, peak daytime PAR while TGM deposition occurred during cooler, low PAR $(<400)$ periods (Fig. 1). The palsa site yielded the highest TGM evasion coupled with the least amount of $\mathrm{Hg}$ deposition during the low PAR hours. The bog exhibited the most variability of the three sites. The strong correlation between TGM flux and PAR in the bog site is consistent with earlier interpretations (Klaminder et al., 2008) of increased photoreduction reactions in water-saturated soils, resulting from permafrost thaw, leading to lower peat $\mathrm{Hg}$ concentrations (Gustin et al., 2006). The bog TGM flux, together with lower $\mathrm{Hg}_{\text {Tot }}$ concentrations deeper in the peat, suggest significant $\mathrm{Hg}$ loss (Klaminder et al., 2008), with the semi-wet or intermediate stage of the thaw resulting in less $\mathrm{Hg}$ retention in soils and vegetation (Fig. 2). The fen site experienced both the lowest TGM evasion and the highest TGM deposition (most negative fluxes). Some studies have found that biotic demethylation of $\mathrm{Hg}$ can be a significant source of evasion (Pannu et al., 2014 and references therein). Both the fen and the palsa sites showed stronger relationships between air temperature and TGM flux and this may influence both biotic and abiotic reactions (Fig. 1).

2. Soil carbon labileness and sulphur redox. The three habitat types representing a permafrost thaw gradient were also characterised by markedly different peat $\mathrm{Hg}_{\mathrm{Tot}}$ concentrations. The palsa site had the highest overall $\mathrm{Hg}_{\mathrm{Tot}}$ with concentrations ranging from $257 \mu \mathrm{g} \mathrm{kg}^{-1}$ near the surface and decreasing to $15 \mu \mathrm{g} \mathrm{kg}^{-1}$ with depth to the active layer boundary (44 $\mathrm{cm}$ from surface) (Fig. S-4). The bog site had the lowest overall $\mathrm{Hg}_{\mathrm{Tot}}$ (concentrations from 10-75 $\mathrm{g} \mathrm{kg} \mathrm{k}^{-1}$ ). The fully thawed fen habitat had intermediate $\mathrm{Hg}_{\mathrm{Tot}}$ concentrations $\left(10-165 \mu \mathrm{g} \mathrm{kg}^{-1}\right)$, with values decreasing gradually with depth as in the palsa. Relative $\mathrm{Hg}_{\mathrm{Tot}}$ pools estimated by combining bulk density at each site (profiled at $\sim 5 \mathrm{~cm}$ increments) with the $\mathrm{Hg}_{\text {Tot }}$ measurements (details in Supplementary Information) followed the same pattern, with; palsa $\left(2.7 \mathrm{mg} \mathrm{m}^{-2}\right)$, bog $\left(1.4 \mathrm{mg} \mathrm{m}^{-2}\right.$ ) and fen (4.7 $\left.\mathrm{mg} \mathrm{m}^{-2}\right)$ (Fig. 2). These findings suggest that the $\mathrm{Hg}$ liberated from thawing palsa has two potential pathways of reallocation; palsa may thaw directly to a bog and from there result in $\mathrm{Hg}$ export, or alternatively palsa may transition directly to a fen where $\mathrm{Hg}$ accumulation is enhanced.

Total peat sulphur (S) concentrations (Fig. S-4) provide additional evidence pointing to $\mathrm{Hg}_{\mathrm{Tot}}$ accumulation. The surface of the fen sites ( 0-1 cm depths) contain almost double the amount of $S$ relative to both the palsa and the bog sites. At the fen, total $\mathrm{Hg}$ shows a strong relationship with $\mathrm{C}, \mathrm{N}$ and $S\left(r^{2}=0.73,0.77,0.82\right)$, whereas in the bog and palsa the correlations are weak or insignificant (Fig. S-5). In reducing environments, $\mathrm{S}$ in peat forms organo-sulphides, especially in the presence of hydrogen sulphide (Schartup et al., 2014) which enhances storage of $\mathrm{Hg}$.

The degree to which these dynamic landscapes might serve as sources of the biologically available and toxic $\mathrm{MeHg}$ was evaluated through the analysis of porewater chemistry. In addition to enhanced peat $\mathrm{Hg}$ accumulation in the fen, we also found elevated concentrations of $\mathrm{MeHg}$ in fen porewater that were similar to those reported in other wetland studies (e.g., Tjerngren et al., 2012). This pattern was in contrast to the notably lower porewater $\mathrm{MeHg}$ concentrations in the bog site (Table S-1). The methylation of $\mathrm{Hg}$ in the mire may be 
a function of bioavailable $\mathrm{Hg}$ and/or linked with the ability of the microbial community to methylate $\mathrm{Hg}$. Differences in redox conditions, organic matter structure and composition, and microbial communities between bog and fen sites may explain the observed differences in $\mathrm{MeHg}$. The presence of higher total $\mathrm{S}$ in the fen site may also enhance the bioavailability of ionic $\mathrm{Hg}$ leading to methylation (Skyllberg et al., 2003). Additionally, the $\mathrm{Hg}$ bound to more labile OC may be more easily methylated by microbes than $\mathrm{Hg}$ bound to more recalcitrant C. Hodgkins et al. (2014) compared the same bog and fen sites in this study, drawing clear distinctions between the compositions of the organic matter. They highlight the ability of Sphagnum to control the rate of decomposition in the bog by producing phenolic compounds. This pattern is in stark contrast to the fen, where decomposition rates highly correspond to microbially derived organic matter (Hodgkins et al., 2016).
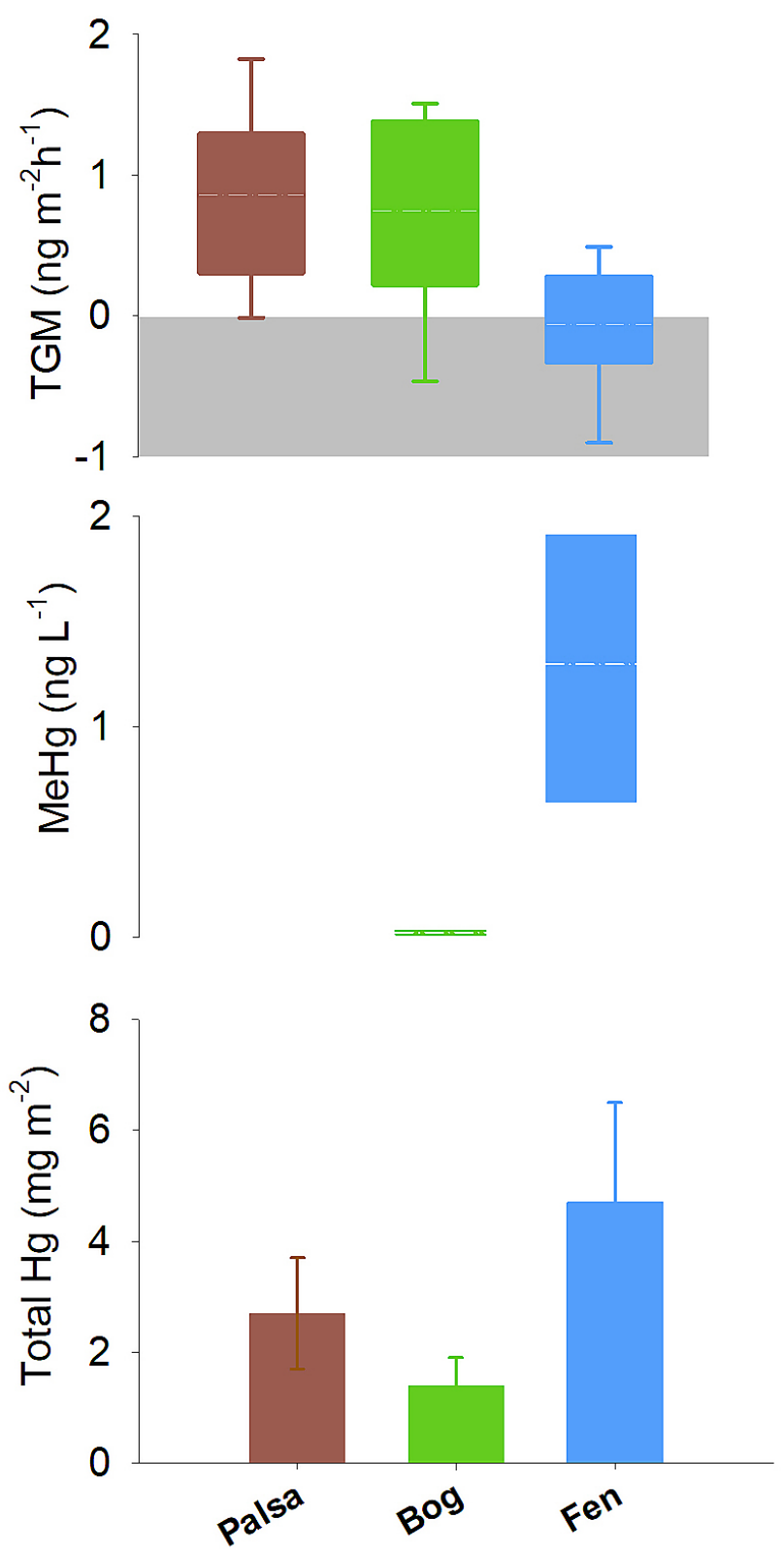

Figure 2 Summarised $\mathrm{Hg}$ in the three sub-habitats (from top to bottom): TGM, porewater methyl $\mathrm{Hg}(\mathrm{MeHg})$, and total peat $\mathrm{Hg}$ (corrected for dry bulk density).
3. Methylation potential of peatland sub-habitats. The microbial communities are markedly different across the palsa, bog and fen as attested by $16 \mathrm{~S}$ rRNA gene analyses (Mondav et al., 2014; 2017). We examined observed lineages for potential $\mathrm{Hg}$ methylators (i.e. microbial genera either experimentally demonstrated to methylate $\mathrm{Hg}$ or inferred to do so by the presence of the $h g c A$ and $h g c B$ genes required for $\mathrm{Hg}$ methylation (Parks et al., 2013; Table S-2; detailed methods in Supplementary Information). These potential Hg-methylating microbes increased across the thaw gradient from low relative abundance in the palsa and bog $(\sim 0.5 \%$ and $\sim 0.7 \%$ of the community, respectively) to markedly higher abundance in the fen ( 7.8 \%) (Fig. 3 and Table S-2). The identified potential $\mathrm{Hg}$-methylators include sulphate- and iron-reducing lineages from the Deltaproteobacteria and Clostridia, as well as methanogens of Methanomicrobia (Table S-2). Methanoregula, an important methanogen at the site (Mondav et al., 2017) and one of the potential Hg-methylators present, was both relatively more abundant and more diverse (more lineages recovered) in the fen. Overall, the presence of a larger and more diverse community of potential $\mathrm{Hg}$-methylators in the fen supports the role of microbes in driving elevated $\mathrm{MeHg}$ in fen porewaters and the presence of potential $\mathrm{Hg}$-methylating methanogens highlights the interacting impacts of permafrost thaw on the production of both methane and $\mathrm{MeHg}$.

\section{A revised framework for $\mathrm{Hg}$ cycling in Arctic ecosystems}

Contrary to earlier conceptual models of $\mathrm{Hg}$ export from Arctic ecosystems (e.g., Klaminder et al., 2008), we found that while $\mathrm{Hg}$ is liberated from peat during the intermediate thaw stage it is subsequently accumulated in a later thaw stage represented in the fen site. Recent studies from Alaska (Obrist et al., 2017; Douglas and Blum, 2019) found TGM uptake by vegetation to be a significant pathway of $\mathrm{Hg}$ accumulation. Increasingly longer growing seasons associated with changing climate (Callaghan et al., 2010 and references therein), coupled with the expansion of fen sites throughout the mire (Johansson et al., 2006a), suggest this mechanism is likely relevant in Stordalen Mire. A second potential fate, depending on the pace of climate change, may be catastrophic collapse of permafrost as observed in the western Canadian Arctic (St. Pierre et al., 2018). This second pathway bypasses the peat or fen storage and flushes large quantities of both total and methyl $\mathrm{Hg}$ from the ecosystem (St. Pierre et al., 2018).

\section{Conclusions}

Examination of $\mathrm{Hg}_{\mathrm{Tot}}$ pools in thawing peat, combined with mechanisms of gaseous $\mathrm{Hg}$ flux and $\mathrm{MeHg}$ production, lead to a revised conceptual model of pathways of $\mathrm{Hg}$ loss and retention in thawing permafrost peatlands (Fig. 4). Taken together, these results suggest a more complex set of processes amongst permafrost thaw regions. During initial stages of permafrost thaw, when the active layer in the palsa deepens, export of gas-phase TGM is a primary pathway of $\mathrm{Hg}$ loss. As the thaw continues vegetation changes to a Sphagnum-dominated semithawed ecosystem, where $\mathrm{Hg}$ export into the atmosphere limits accumulation of $\mathrm{Hg}$ in peat and the peat bound $\mathrm{Hg}_{\mathrm{Tot}}$ pool is depleted. The final stage of thaw, characterised by fully thawed fens, results in a more biologically mobile $\mathrm{Hg}$ pool. This transition is facilitated via favourable redox conditions, more labile organic matter and a diverse microbial community capable of methylation, resulting in greater $\mathrm{Hg}$ retention in fen peat and also higher levels of porewater $\mathrm{MeHg}$ that may be exported to nearby lakes and streams. Given the prediction 


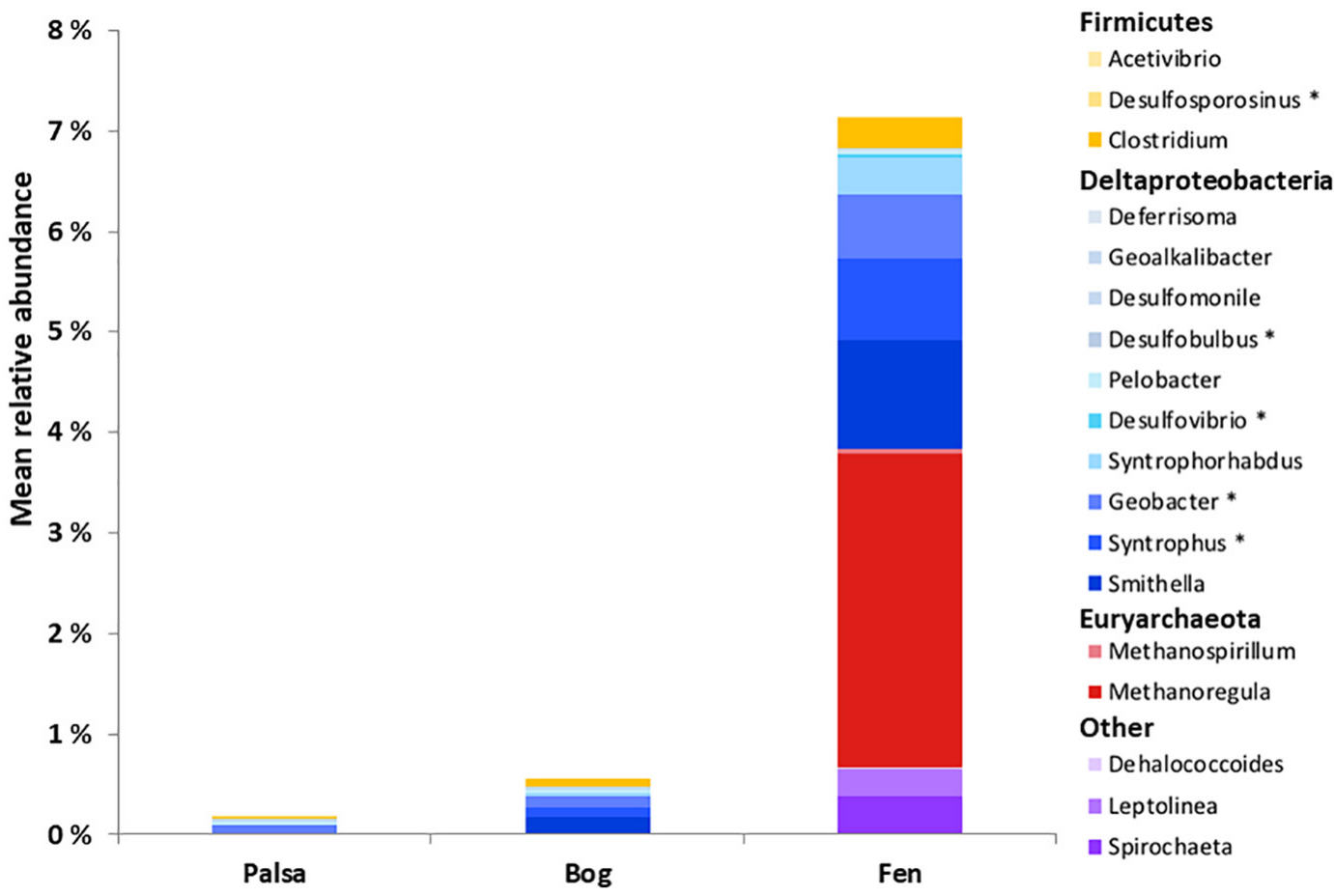

Figure 3 Mean relative abundance of potential Hg methylators at Stordalen Mire ( $n=38$ for palsa, 47 for bog, and 42 for fen), using microbial community data from 2010-2012 reanalysed from Mondav et al. (2017). * indicates genera with members experimentally confirmed to methylate $\mathrm{Hg}$.

\section{Permafrost Thaw}
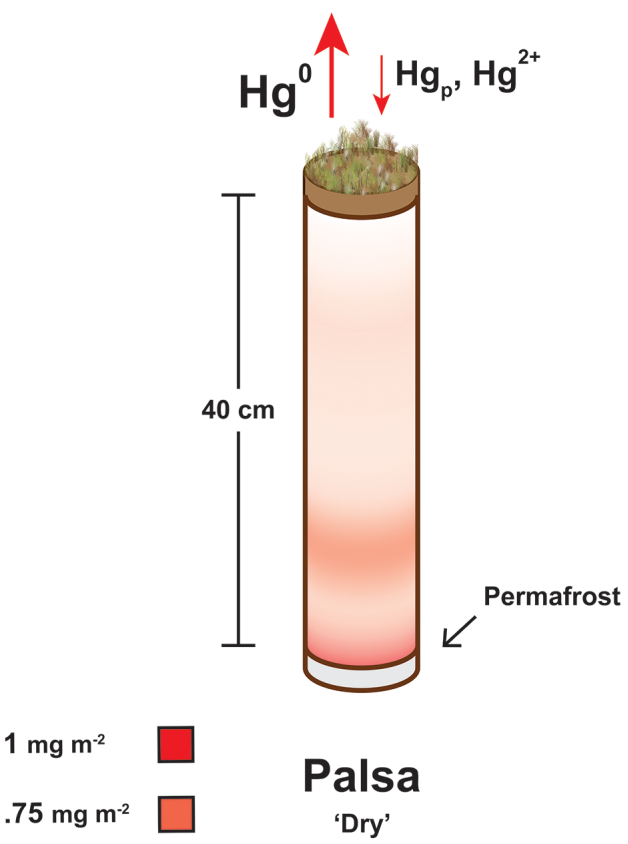

$.5 \mathrm{mg} \mathrm{m}^{-2}$

$.25 \mathrm{mg} \mathrm{m}^{-2}$

$0 \mathrm{mg} \mathrm{m}^{-2}$

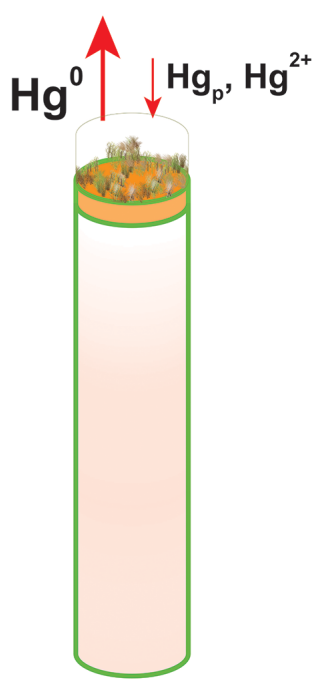

Bog

Semi-Thawed Aerobic/Anaerobic

High DOC
$\mathrm{pH}=4.2$

Recalcitrant C Low Decomposition

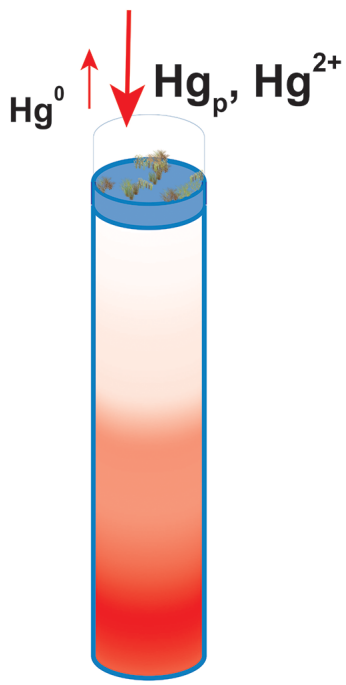

Fen

Fully-Thawed

$\mathrm{HgS}, \mathrm{Hg}^{2+}, \mathrm{CH}_{4}$ $\mathrm{Hg}$ o/i complexes High porewater MeHg

Low DOC

$\mathrm{pH}=\mathbf{5 . 7}$

High Decomposition

Figure 4 Schematic of biogeochemical $\mathrm{Hg}$ cycling across permafrost thaw with emphasis on $\mathrm{Hg}$ pools and major pathways. Red arrows denote gaseous $\left(\mathrm{Hg}^{0}\right)$ flux for each stage of the thaw sequence. Peat inventories are for total $\mathrm{Hg}$ for the top $40 \mathrm{~cm}$ of the mire surface (cf. legend for corresponding range). 
of loss of discontinuous zone permafrost by 2100 (Slater and Lawrence, 2013), it is imperative that long term studies coupling $\mathrm{Hg}$ cycling, microbial community composition and mechanisms driving gene expression of $\mathrm{Hg}$ methylation as well as varying environmental conditions are carried out to improve predictions of the fate of $\mathrm{Hg}$ stored in permafrost within these dynamically changing ecosystems.

\section{Acknowledgements}

We thank the Abisko Scientific Research Station and Dr. R. Geisler for infrastructure and logistical support. We also thank N. Rakos, C. Hemmingsson and L. Erickson for field sampling assistance, members of ISOGENIE 2013 sampling personnel, B. Verbek and R. Wilson of FSU for bulk density data and Dr. S. Frey and M. Knorr for sample preparation assistance. This work was funded by an UNH Earth Sciences Graduate Research Award, the Karen Von Damm Memorial Student Award, the Karen Von Damm Leadership Development Award (JGB), NSF1255888 (JGB) and associated technical support from UNH, the Iola Hubbard Climate Change Endowment (RKV, JGB), the Northern Ecosystems Research for Undergraduates (NSF1063037), the Macrosystems Biology (NSF EF\#1241037 (RKV) and by the Genomic Science Program of the United States Department of Energy Office of Biological and Environmental Research, grants DE-SC0010580 and DE-SC0016440.

\section{Editor: Karim Benzerara}

\section{Additional Information}

Supplementary Information accompanies this letter at http:// www.geochemicalperspectivesletters.org/article1922.

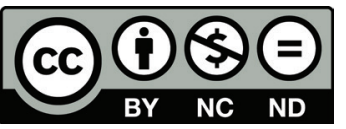

This work is distributed under the Creative Commons Attribution Non-Commercial No-Derivatives 4.0 License, which permits unrestricted distribution provided the original author and source are credited. The material may not be adapted (remixed, transformed or built upon) or used for commercial purposes without written permission from the author. Additional information is available at http://www.geochemicalperspectivesletters.org/ copyright-and-permissions.

Cite this letter as: Fahnestock, M.F., Bryce, J.G., McCalley, C.K., Montesdeoca, M., Bai, S., Li, Y., Driscoll, C.T., Crill, P.M., Rich, V.I., Varner, R.K. (2019) Mercury reallocation in thawing subarctic peatlands. Geochem. Persp. Let. 11, 33-38.

\section{References}

BÄCKSTRAND, K. CRILl, P.M., JACKOWICZ-KorCZyÑSKI, M., MASTEPAnOV, M., Christensen, T.R., BAstviken, D. (2010) Annual carbon gas budget for a subarctic peatland, Northern Sweden. Biogeosciences 7, 95-108

BARkAY, T., KRoer, N., Poulain, A.J. (2011) Some like it cold: microbial transformations of mercury in polar regions. Polar Research 30, 15469.

Callaghan, T.V., Bergholm, F., Christensen, T.R., Jonasson, C. KoKfelt, U., JohANSSON, M. (2010) A new climate era in the sub Arctic: Accelerating climate changes and multiple impacts. Geophysical Research Letters 37, L14705.

CARPI, A., LindBERG, S.E. (1997) Sunlight-Mediated emission of elemental mercury from soil amended with municipal sewage sludge. Environmental Science \& Technology 31, 2085-2091.

Douglas, T.A., BLuM, J.D. (2019) Mercury isotopes reveal atmospheric gaseous mercury deposition directly to the Arctic coastal snowpack. Environmental Science \& Technology Letters 6, 235-242.
Fitzgerald, W.F., Engstrom, D.R., LamborG, C.H., Tseng, C., Balcom, P.H., HAMmerschmidT, C.R. (2005) Modern and historic atmospheric mercury fluxes in northern Alaska: Global sources and arctic depletion. Environmental Science \& Technology 39, 557-568.

GRIGAL, D.F. (2003) Mercury sequestration in forests and peatlands: a review. Journal of Environmental Quality 32, 393-405.

Gustin, M.S., Engle, M., Ericksen, J., Lyman, S., Stamenkovi, J., Xin, M. (2006) Mercury exchange between the atmosphere and low mercury containing substrates. Applied Geochemistry 21, 1913-1923.

Hodgkins, S.B., Tfaily, M.M., McCalley, C.K., Logan, T.A., Crill, P.M., SAleskA, S.R., Rich, V.I., Chanton, J.P. (2014) Changes in peat chemistry associated with permafrost thaw increase greenhouse gas production. Proceedings of the National Academy of Science $111,5819-5824$

Hodgkins, S.B., Tfaily, M.M., Podgorski, D.C., MCCalley, C.K., Saleska, S.R., Crill, P.M., Rich, V.I., Chanton, J.P., CoOper, W.T. (2016) Elemental composition and optical properties reveal changes in dissolved organic matter along a permafrost thaw chronosequence in a subarctic peatland. Geochimica et Cosmochimica Acta 187, 123-140.

Johansson, T., Malmer, N., Crill, P.M., Friborg, T., Åkerman, J.H., Mastepanov, M., Christensen, T.R. (2006a) Decadal vegetation changes in a northern peatland, greenhouse gas fluxes and net radiative forcing. Global Change Biology 12, 2352-2369.

Johansson, M., Christensen, T.R., Åkerman, H.J., Callaghan, T.V. (2006b) What Determines the Current Presence or Absence of Permafrost in the Torneträsk Region, a Sub-arctic Landscape in Northern Sweden? AMBIO: A Journal of the Human Environment 35, 190-197.

Klaminder, J., Yoo, K., RydberG, J., Giesler, R. (2008) An explorative study of mercury export from a thawing palsa mire. Journal of Geophysical Research: Biogeosciences 113, G04034.

Malmer, N., Johansson, T., Olsrud, M., Christensen, T.R. (2005) Vegetation, climatic changes and net carbon sequestration in a North-Scandinavian subarctic mire over 30 years. Global Change Biology 11, 1895-1909.

Monday, R., Woodcroft, B.J., Kim, E., McCalley, C.K., Hodgkins, S.B., Crill, P.M., Chanton, J., Hurst, G.B., VerBerkmoes, N.C., SaleskA, S.R., Hugenholtz, P., Rich, V.I., TYson, G.W. (2014) Discovery of a novel methanogen prevalent in thawing permafrost. Nature Communications 5, 3212 .

Monday, R., McCalley, C.K., Hodgkins, S.B., Frokling, S., SAleska, S.R., Rich, V.I., Chanton, J.P., CRILl, P.M. (2017) Microbial network, phylogenetic diversity and community membership in the active layer across a permafrost thaw gradient. Environmental Microbiology 19, 3201-3218.

Mu, C., Zhang, F., Chen, X., Ge, S., Mu, M., Jia, L., Wu, Q., Zhang, T. (2019) Carbon and mercury export from the Arctic rivers and response to permafrost degradation. Water Research 161, 54-60.

Obrist, D., Agnan, Y., Jiskra, M., Olson, C.L., Colegrove, D.P., Hueber, J., Moore, C.W., Sonke, J.E., Helmig, D. (2017) Tundra uptake of atmospheric elemental mercury drives Arctic mercury pollution. Nature 547, 201-204.

ÖQUIST, M.G., SvensSON, B.H. (2002) Vascular plants as regulators of methane emissions from a subarctic mire ecosystem. Journal of Geophysical Research 107, 4580

Pannu, R., Siciliano, S.D., O’Driscoll, N.J. (2014) Quantifying the effects of soil temperature, moisture and sterilization on elemental mercury formation in boreal soils. Environmental Pollution 193, 138.

PARKs, J.M., Johs, A., Podar, M., Bridou, R., Hurt JR., R.A., SMith, S.D., TomaniceK, S.J., Qian, Y., Brown, S.D., Brandt, C.C., Palumbo, A.V., Smith, J.C., Wall, J.D., Elias, D.A., Liang, L. (2013) The Genetic Basis for Bacterial Mercury Methylation. Science $339,1332-1335$

Poissant, L., Pilote, M., Xu, X., Zhang, H., Beauvais, C. (2004) Mercury Gas Exchanges over Selected Bare Soil and Flooded Sites in the Bay St. François Wetlands (Québec, Canada). Atmospheric Environment 38, 4205-4214.

RydberG, J., Klaminder, J., Rosén, P., Bindler, R. (2010) Climate driven release of carbon and mercury from permafrost mires increases mercury loading to sub-arctic lakes. Science of The Total Environment $408,4778-4783$

Schartup, A.T., BALCOM, P.H., MASON, R.P. (2014) Sediment-porewater partitioning, total sulfur, and methylmercury production in estuaries. Environmental Science \& Technology 48, 954-960

Schuster, P.F., Schaefer, K.M., Aiken, G.R., Antweiler, R.C., Dewild, J.F., Gryziec, J.D., Gusmeroli, A., Hugelius, G., Jafarov, E., Krabbenhoft, D.P., LiU, L., Herman-Mercer, N., Mu, C., Roth, 
D.A., Schaefer, T., Striegl, R.G., Wickland, K.P., Zhang, T. (2018) Permafrost Stores a Globally Significant Amount of Mercury. Geophysical Research Letters 45, 1463-1471.

SELIN, N.E. (2009) Global biogeochemical cycling of mercury: a review. Annual Review of Environment and Resources 34, 43-63.

SkyllberG, U., Qian J., Frech, W., Xia, K., Bleam, W.F. (2003) Distribution of mercury, methyl mercury and organic sulphur species in soil, soil solution and stream of a boreal forest catchment. Biogeochemistry $64,53-76$

Slater, A.G., LaWrence, D.M. (2013) Diagnosing present and future permafrost from climate models. Journal of Climate 26, 5608.

Smith-Downey, N.V., Sunderland, E.M., JACOB, D.J. (2010) Anthropogenic impacts on global storage and emissions of mercury from terres trial soils: Insights from a new global model. Journal of Geophysical Research: Biogeosciences 115, G03008.

St. Pierre, K.A., Zolkos, S., Shakil, S., Tank, S.E., St. Louis, V.L KoKeLJ, S.V. (2018) Unprecedented Increases in Total and Methyl Mercury Concentrations Downstream of Retrogressive Thaw Slumps in the Western Canadian Arctic. Environmental Science \& Technology 52, 14099-14109.

Tjerngren, I., Karlsson, T., Bjorn, E., Skyllberg, U. (2012) Potential $\mathrm{Hg}$ methylation and $\mathrm{MeHg}$ demethylation rates related to the nutrient status of different boreal wetlands. Biogeochemistry 108, 335-350.

YANG, Z., FANG, W., LU, X., Sheng, G.P., Graham, D.E., LiAnG, L., Wullschleger, S.D., GU, B. (2016) Warming increases methylmercury production in an Arctic soil. Environmental Pollution 214, 504-509. 